\title{
JURNAL
}

TEKNOLOGI INFORMASI

\section{IMPLEMENTASI METODE FORWARD CHAINING PADA SISTEM PAKAR DIAGNOSIS KEPERAWATAN PENYAKIT STROKE INFARK}

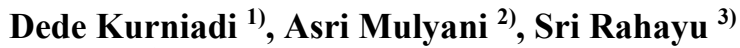 \\ ${ }^{1,2,3)}$ Sekolah Tinggi Teknologi Garut \\ Jl. Mayor Syamsu No. 1, Jayaraga, Garut \\ Email : 'dede.kurniadi@sttgarut.ac.id
}

\begin{tabular}{lcc}
\hline & Riwayat artikel: & \\
Recieved: 07-02-2021 & Revised:10-02-2021 & Accepted:10-02-2021 \\
\hline
\end{tabular}

\begin{abstract}
Patients who have been medically diagnosed, namely stroke infarction and undergoing treatment in the hospital, may leave interference from the effects of stroke infarction. One of the disturbances that arise in patients with stroke infraction is the barrier to physical mobility. Some treatments can be done for infarct stroke patients with impaired physical mobility, including mobilization exercises and Active Range of Motion. This treatment is very effective in preventing stiffness in the muscles. The purpose of this study was to develop an expert system application to assist stroke infarction patients in identifying disorders that may arise after discharge from the hospital. The conclusion method uses Forward Chaining and for system development with the Expert System Development Life Cycle approach. We tested 10 samples based on the real nurse diagnosis results with the results of the expert system diagnosis made. The comparison of testing the results of the system diagnosis shows an accuracy rate of 90 percent so that the expert system made is suitable for use.
\end{abstract}

Keywords: Nursing Diagnosis, Forward Chaining, Expert System, Stroke Infarction

\begin{abstract}
Abstrak
Pasien yang telah di diagnosa secara medis yaitu stroke infark dan menjalankan perawatan di rumah sakit mungkin akan meninggalkan gangguan dari dampak penyakit stroke infark. Salah satu gangguan yang muncul pada penderita stroke infrak yaitu hambatan mobilitas fisik. Adapun peerawatan yang dapat dilakukan untuk pasien stroke infark dengan gangguan hambatan mobilitas fisik diantaranya degan latihan mobilisasi dan melakukan Range of Motion aktif. Perawatan ini sangat efektif untuk mencegah terjadinya ke kakuan pada otot-otot. Penelitian ini betujuan untuk mengembangkan aplikasi sistem pakar untuk membantu pasien stroke infark dalam mengetahui gangguan yang mungkin muncul setelah keluar dari rumah sakit. Metode penarikan kesimpulan mengggunakan Forward Chaining dan untuk pengembangan sistem dengan pendekatan Expert System Development Life Cycle. Kami menguji 10 sample berdasarkan hasil diagnosis perawat sesungguhnya dengan hasil diagnosa sistem pakar yang dibuat. Hasil dari perbandingan pengujian hasil diagnosis sistem menunjukan tingkat akurasi 90 persen sehingga sistem pakar yang dibuat layak untuk digunakan.
\end{abstract}

Kata kunci: Sistem Pakar, Diagnosa Keperawatan, Forward Chaining, Stroke Infark. 


\section{Pendahuluan}

World Health Organization (WHO) menyatakan bahwa penyakit stroke merupakan penyakit yang disebabkan karena gangguan otak dengan gejala yang berlangsung selama 24 jam atau lebih dan dapat berkembang cepat hingga mengakibatkan adanya kematian. Penyakit ini termasuk pendarahan subarachnoid, pendarahan intraserebral, dan infark serebral. Stroke dibagi menjadi dua yaitu stroke infark dan stroke hemoragik. Berdasarkan riset kesehatan dasar (RISKESDES) pravalensi kasus stroke di Indonesia berdasarkan tenaga kesehatan sebesar 11 permil, di Garut khusunya di RSUD dr. Slamet di ruang Rubi jumlah penderita stroke infark sangat tinggi yaitu 30,97 persen dari periode Januari-Mei 2019, hal ini menujukan angka stroke infark masih tinggi [1].

Penatalaksanaan penderita terbagi dalam 3 fase yaitu fase hiperakut, akut dan pemulihan. Fase hiperakut merupakan fase segera setelah pasien terserang stroke. Pada fase yang pertama ini, prinsip perawatannya adalah penolong harus mempertahankan jalan nafas penderita stroke tetap lancar. Fase yang kedua adalah fase akut, dimana idealnya pasien dirawat di ruang unit stroke. Ruang unit stroke ini merupakan ruangan rawat khusus untuk merawat penderita stroke sejak fase akut hingga fase pemulihan. Fase yang ketiga yaitu fase pemulihan, dimana kondisi pasien stabil dan fase akut telah dilalui. Penderita stroke sangat membutuhkan penanganan yang kompherensif, termasuk upaya pemulihan dan rehabilitas dalam kurun waktu yang lama bahkan sepanjang sisa hidup penderita stroke. Pada fase ini, keluarga sangat berperan dalam penyembuhan atau pemuliahn penderita stroke sehingga sejak awal perawatan, keluarga diharapkan terlibat dalam penanganan pasien [2].

Berdasarkan uraian di atas, penelitian ini akan membahas bagaimana membuat sistem pakar yang dapat mendiagnosa penyakit stroke infark berdasarkan diagnosis keperawatan. Diagnosis keperawatan ini bertujuan untuk menentukan perawatan seperti apa yang dapat dilakukan keluarga pasien untuk merawat pasien stroke infark setelah keluar dari rumah sakit. Perawatan ini nantinya dapat dilakukan di rumah sendiri. Tentunya pakar pada penelitian ini yaitu perawat, karena perawat melakukan perawatan yang kebanyakan dapat diterapkan oleh masyarakat awam. Metode yang digunakan untuk penalaran pada penelitian ini yaitu metode penarikan kesimpulan forward chaining dengan pola penelusuran breadth first search dalam mendiagnosa penyakit stroke infark berdasarkan gejalagejala yang dialami saat ini. Menurut Angga forward chaining merupakan suatu teknik penarikan kesimpulan berdasarkan fakta-fakta [8]. Sistem pakar ini diharapkan dapat membantu pemulihan pasien yang telah di diagnosa stroke infark secara medis terhadap gangguan-gangguan yang muncul pada pasien stroke infark agar mengurangi gejala gangguan yang timbul pada pasien stroke infark dengan 
perawatan yang dapat dilakukan di rumah sendiri tanpa bantuan dari seorang perawat.

\section{Kajian Pustaka}

Sistem pakar merupakan salah satu cabang kecerdasan buatan yang dikembangkan dengan memanfaatkan adanya pengetahuan khusus yang dimiliki oleh pakar dalam menyelesaikan masalah-masalah tertentu (Riley \& Giarratano, 2005) Sistem pakar ini berfungsi menirukan pakar (manusia) yang harus bisa melakukan hal-hal yang dapat dilakukan oleh seorang pakar. Penelitian ini merujuk pada penelitian sebelumnya yaitu penelitian pertama membuat sistem pakar diagnosa penyakit stroke menggunakan metode Dempster Shafer dengan menghasilkan sistem pakar yang berfungsi untuk mendiagnosa penyakit stroke berdasarkan inputan dari gejala umum pasien [3]. Penelitian kedua membuat sistem pakar untuk deteksi dini penyakit stroke menggunakan metode Naive BayesCertainty Factor, sistem pakar ini dapat menghasilkan diagnosa berupa deteksi penyakit stroke berdasarkan faktor resiko secara dini [4]. Penelitian ketiga merancang dan membuat sistem pakar diagnosa penyakit pada ikan cupang, metode yang digunakan yaitu Naive Bayes untuk menghitung peluang bahwa ikan tersebut terkena penyakit [5]. Penelitian keempat mengenai pengembangan sistem pakar diagnosis penyakit untuk tanaman tomat yang berfungsi untuk mendiagnosa penyakit pada tanaman tomat berdasarkan gejala yang dapat dilihat pada tanaman tomat dengan metode pengembangan sistem yang digunakan adalan Expert System Developer Life Cycle (ESDLC) [6]. Penelitian kelima membuat sistem pakar untuk menentukan jenis gangguan kejiwaan menggunakan metode penelusuran data Breadth First Search (BFD) [7].

Untuk mengembangkan sistem pakar, maka komponen-komponen yang harus dimiliki adalah sebagai berikut [9] : (1) antar muka pengguna (user interface), merupakan perantara komunikasi antara sistem dan pengguna; (2) basis pengetahuan (knowledge base), yang merupakan kumpulan pengetahuanpengetahuan pada bidang tertentu dan format tertentu dengan tingkatan pakar; (3) memori kerja (working memori), merupakan komponen sistem pakar yang menyimpan fakta yang didapatkan saat melakukan konsultasi; (4) mesin inferensi (inference machine), merupakan sofware yang melakukan tugas inferensi penalaraan tentang inormasi yang ada dalam basis pengetahuan, dan untuk menarik kesimpulan. Mesin inferensi ini akan mencari solusi dari suatu permasalahan, mengandung mekanisme pola pikir dan penalaran yang digunakan oleh pakar dalam menyelesaikan masalah.

Terdapat dua metode utama dalam mekanisme inferensi dalam stsitem pakar yaitu forward chaining dan backward chaining. Metode forward chaining 
merupakan metode menarik kesimpulan dari fakta-fakta yang telah diketahui untuk mendapatkan suatu fakta baru dengan memakai aturan-aturan (rules) yang cocok dengan fakta dan terus dilanjutkan sampai mendapat kesimpulan atau sampai tidak ada aturan (rule) yang cocok atau sampai mendapatkan fakta. Metode forward chaining menggunakan pendekatan datadriven (berorientasi data), dalam pendekatan ini diawali dari informasi atau fakta yang ada, kemudian mencoba menggambarkan kesimpulan. Komputer akan menganalisis permasalahan dengan mencocokan menggunakan bagian IF dari rule IF-THEN [10].

\section{Metode Penelitian}

\section{Metode Forward Chaining}

Metode Forward Chaining merupakan metode penarikan kesimpulan yang dimulai dari fakta untuk menguji hipotesa menuju kesimpulan. Pencocokan fakta atau pernyataan dimulai dengan IF (jika) untuk menguji hipotesa. Metode Forward chaining melakukan pencarian dari suatu masalah kepada solusinya. Berikut gambar pola metode forward chaining: [11]

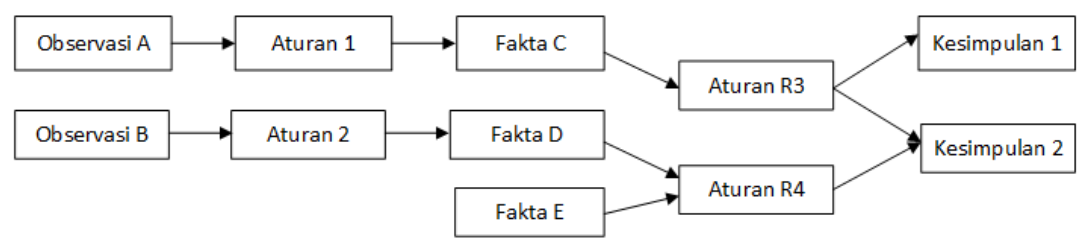

Gambar 1. Pola Metode Forward Chaining

Mekanisme metode forward chaining dalam diagnosis keperawatan pada penderita penyakit stroke fakta yang telah diketahui [12].

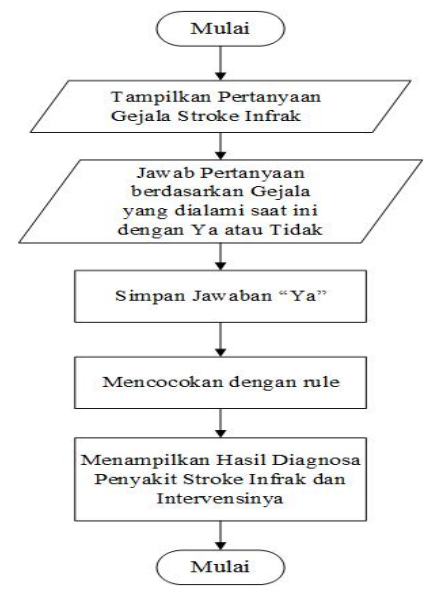

Gambar 2. Mekanisme metode forward chaining pada Sistem Pakar 


\section{Metode Pengembangan Sistem}

Metode yang digunakan dalam pengembangan sistem pakar diagnosis keperawatan penyakit stroke infrak adalah Expert System Developer Life Cycle (ESDLC). Menurut John Durkin metedologi ESDLC terdiri dari beberapa tahapan yaitu sebagai berikut [5]:

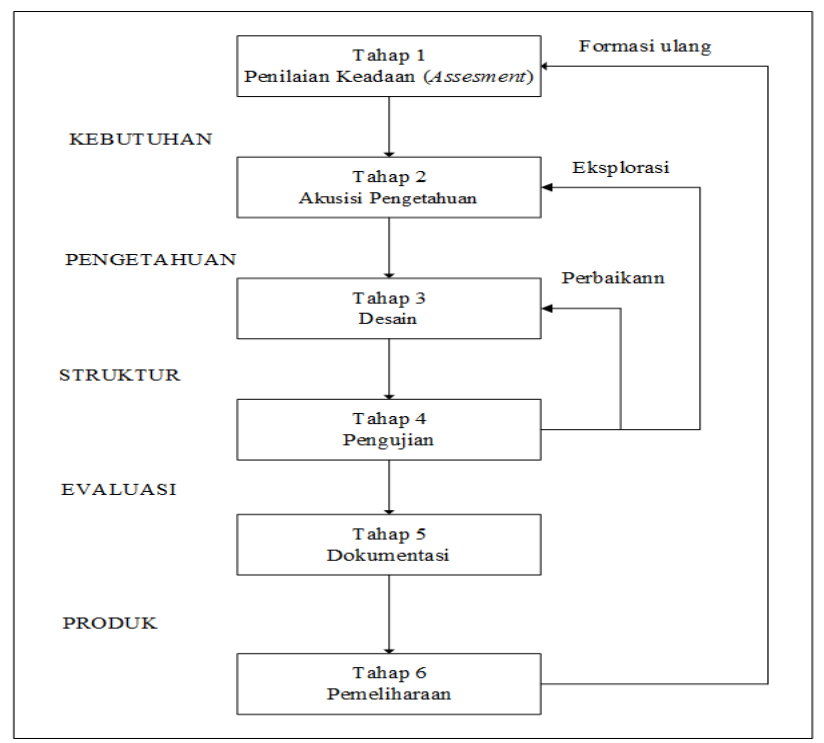

Gambar 3. Tahap Pengembangan Sistem Pakar

Adapun penjelasan berdasarkan Gambar 3 adalah sebagai berikut. Tahap penilaian keadaan (assesment) adalah tahap penentuan hal-hal yang penting sebagai dasar dari permasalahan dengan menganalisa dan membatasi masalah yang akan diimplementasikan. Tahap akusisi pengetahuan (knowledge acquisition) dilakukan untuk mengetahui pengetahuan yang akan digunakan sebagai acuan dalam upaya pengembangan sistem pakar dengan pengumplan data kemudian menghimpun pengetahuan dan aturan-aturan (rules) yang menetukan relasi dan posisi pengetahuan dengan menyusun tabel hasil akusisi pengetahuan. Perancangan (Design) merupakan suatu proses perancangan dan cara sistem dapat berjalan seperti yang diharapkan sesuai dengan kebutuhan. Pada tahap desain sistem pakar ini berisi tentang penetapan keseluruhan struktur sistem dan pembangunan prototype sistem. Pengujian (Testing), merupakan evaluasi terhadap sistem yang telah dibuat. Pengujian yang digunakan adala pengujian Black box yaitu pengujian yang focus dalam memperhatikan faktor fungsionalitas sistem dan spesifikasi dari perangkat lunak. Dokumentasi (documentation) merupakan suatu teknik dokumentasi yang bermanfaat bagi pengguna (user). Dokumentasi dapat berbentuk catatan penting, seperti tampilan antarmuka sistem, source code dan sebagainya. 
Sedangkan tahap pemeliharaan (maintenance) merupakan aktivitas yang dilakukan untuk memelihara dan merawat sistem yang telah dibangun tersebut.

\section{Hasil dan Pembahasan}

Tujuan dari penelitian ini adalah membantu pasien stroke infark yang telah keluar dari rumah sakit untuk mengetahui gangguan yang mungkin muncul pada penderita stroke infark berdasarkan gejala yang dialami saat ini. Penelitian ini menerapkan metode penarikan kesimpulan forward chaining dan menghasilkan aplikasi berbasis website dengan pendekatan sistem pakar untuk mendiagnosa penyakit stroke infark berdasarkan diagnosis keperawatan. Hasil dari penelitian ini berupa rancangan sistem pakar diagnosis keperawatan penyakit stroke infark dan aplikasi diagnosis keperawatan penyakit stroke infark menggunakan metode forward chaining. Aplikasi ini dapat menghasilkan satu diagnosa atau lebih diagnosa sesuai dengan apa saja gejala yang dialami saat ini. Berikut merupakan uraian secara rinci mengenai pengembangan sistem pakar.

1. Penentuan Pakar

Pakar merupakan seorang individu yang memiliki pengetahuan khusus, pengalaman, pemahaman dan metode-metode yang digunkaan dalam memecahkan persoalan dalam bidang tertentu. Pakar yang terlibat pada penelitian ini adalah perawat yang memiliki pengalaman dan berfungsi sebagai narasumber diagnosis keperawatan pada penyakit stroke infark yaitu Risma Paujiah Amd. Kep dan Rani Agustin Amd.Kep. Diagnosis keperawatan ini bertujuan untuk menentukan perawatan seperti apa yang dapat dilakukan kelurga pasien stroke infark untuk merawat pasien stroke infark dirumah sendiri untuk mencegah stroke infark dan menanggunalangi gejala-gejala stroke infark.

2. Akusisi Pengetahuan

Berikut ini adalah penyusunan tabel data penyakit stroke infrak.

Tabel 1. Data Penyakit Stroke Infark

\begin{tabular}{cccl}
\hline No & $\begin{array}{c}\text { Kode } \\
\text { Penyakit }\end{array}$ & \multicolumn{1}{c}{$\begin{array}{c}\text { Nama } \\
\text { Penyakit }\end{array}$} & \multicolumn{1}{c}{ Intervensi } \\
\hline 1 & DS001 & Penurununan & Menganjurkan untuk istirahat total. Posisi kepala \\
& & Perfusi & diusahakan lebih tinggi 15-30 cm dari posisi \\
& & Jaringan & jantung. Hindari batuk serta mengejan yang \\
& & & berlebihan. Usahakan suaana tenang. Anjurkan \\
& & keluarga untuk berbicara walaupun lewat sentuhan. \\
& & & Berikan obat berdasarkan program atau protokol. \\
& & Berikan makanan porsi sedikit tapi sering.
\end{tabular}




\begin{tabular}{|c|c|c|c|}
\hline No & $\begin{array}{c}\text { Kode } \\
\text { Penyakit }\end{array}$ & $\begin{array}{c}\text { Nama } \\
\text { Penyakit }\end{array}$ & Intervensi \\
\hline 2 & DS002 & $\begin{array}{l}\text { Kerusakan } \\
\text { Mobilitas } \\
\text { Fisik }\end{array}$ & $\begin{array}{l}\text { Ubah posisi terlentang atau miring setiap } 2 \text { jam } \\
\text { sekali. Posisi telungkup dilakukan satu atau dua } \\
\text { kali. Usahakan latihan gerakan aktif dan pasif } \\
\text { seperti meremas bola karet, melebarkan jari-jari. } \\
\text { Lutut dan pinggul dalam posisi ekstensi serta } \\
\text { lakukan ROM aktif }\end{array}$ \\
\hline 3 & DS003 & $\begin{array}{l}\text { Hambatan } \\
\text { Komunikasi } \\
\text { Verbal }\end{array}$ & $\begin{array}{l}\text { Mengatakan kepada pasien untuk bicara langsung } \\
\text { dengan beberapa pertanyaan terbuka (jawaban "Ya" } \\
\text { atau "Tidak"), serta kemudian berikan pertanyaan } \\
\text { yang lebih kompleks sesuai respon pasien. Mintalah } \\
\text { pasien untuk membaca kalimat pendek serta } \\
\text { menunjukan dan menyebut nama benda. }\end{array}$ \\
\hline 4 & DS004 & $\begin{array}{l}\text { Ketidak } \\
\text { seimbangan } \\
\text { nutrisi }\end{array}$ & $\begin{array}{l}\text { Kebutuhan nutrisi perlu diperhatikan. Berdiskusi } \\
\text { dengan ahli gizi untuk menentukan jumlah kalori } \\
\text { dan nutrisi yang dibutuhkan pasien. }\end{array}$ \\
\hline 5 & DS005 & $\begin{array}{l}\text { Defisit } \\
\text { Perawatan } \\
\text { Diri }\end{array}$ & $\begin{array}{l}\text { Tentukan kemampuan dan tingkat kekurangan } \\
\text { dalam melakukan perawatan diri. Sediakan pakaian } \\
\text { pasien pada tempat yang mudah dijangkau. } \\
\text { Memfasilitasi mandi pasien. Menjaga kebersihan } \\
\text { natural. Melakukan fisiotrapi seminggu sekali. }\end{array}$ \\
\hline 6 & DS006 & $\begin{array}{l}\text { Resiko } \\
\text { Kerusakan } \\
\text { Integritas } \\
\text { Kulit }\end{array}$ & $\begin{array}{l}\text { Anjurkan pasien untuk berpakaian longgar. } \\
\text { Anjurkan melakukan ROM. Ubah posisi setiap } 2 \\
\text { jam sekali. Gunakan bantal air dibawah daerah } \\
\text { yang menonjol. Jaga kulit agar tetap kering dan } \\
\text { bersih. Hindari panas pada kulit dengan } \\
\text { mengoleskan minyak atau lotion pada daerah yang } \\
\text { tertekan. }\end{array}$ \\
\hline
\end{tabular}

Sedangkan untuk data gejala penyakit stroke infrak disajikan pada Tabel 2.

Tabel 2. Gejala Penyakit Stroke Infrak

\begin{tabular}{ccl}
\hline No & Kode Gejala & \multicolumn{1}{c}{ Nama Gejala } \\
\hline 1 & GS001 & Mengalami penurunan kesadaran \\
2 & GS002 & Merasa Gelisah \\
3 & GS003 & Sakit kepala (Pusing) \\
4 & GS004 & Nyeri dada \\
5 & GS005 & Mengalami kelumpuhan atau kelemahan pada anggota tubuh \\
6 & GS006 & Sulit menggerakan anggota gerak \\
7 & GS007 & Aktivitas dibantu/ pergerakan lambat \\
8 & GS008 & Enggan melakukan pergerakan \\
9 & GS009 & Merasa cemas saat bergerak \\
10 & GS010 & Tidak dapat berbicara \\
11 & GS011 & Tidak adanya respon ketika diajak komunikasi secara verbal.
\end{tabular}


AITI: Jurnal Teknologi Informasi

Volume 17 No. 2 Agustus 2020, 104-117

\begin{tabular}{ccl}
\hline No & Kode Gejala & \\
\hline 12 & GS012 & Sulit mengungkapkan kata-kata \\
13 & GS013 & Penurunan berat badan \\
14 & GS014 & Makan 1/2 porsi tidak habis \\
15 & GS015 & Nyeri saat menelan \\
16 & GS016 & Kurang minat pada makanan \\
17 & GS017 & Lesu \\
18 & GS018 & Bau badan \\
19 & GS019 & Kuku panjang \\
20 & GS020 & Wajah tampak kusut \\
21 & GS021 & Rambut dan kulit kotor \\
22 & GS022 & Penampilan tidak rapih \\
23 & GS023 & Mengeluh adanya luka di bagian belakang, tumit, betis, punggung. \\
24 & GS024 & Kulit lecet dan kemerahan \\
25 & GS025 & Gatal-gatal pada kulit \\
26 & GS026 & Tidak banyak bergerak \\
\hline
\end{tabular}

\section{Representasi Pengetahuan}

Penerapan metode penarikan kesimpulan forward chaining disajikan dalam bentuk representasi pengetahuan yaitu kaidah produksi. Kaidah produksi ini bagian dari repsentasi pengetahuan yang pada umumnya, memuat sebuah kondisi (IF) dan aksi (THEN). Bagian ini menunjukkan langkah-langkah yang harus dilakukan, dimulai dari pengetahuan yang didapatkan sehingga sampai pada bentuk kaidah produksi. Tahap ini adalah menyajikan pengetahuan ke dalam bentuk tabel keputusan seperti pada Tabel 3.

Tabel 3. Tabel Keputusan Diagnosis Kperawatan Penyakit Stroke Infark

\begin{tabular}{ccccccc}
\hline DS & DS001 & DS002 & DS003 & DS004 & DS005 & DS006 \\
GS & & & & & \\
\hline GS001 & $\checkmark$ & & & & \\
GS002 & $\checkmark$ & & & & \\
GS003 & $\checkmark$ & & & & \\
GS004 & $\checkmark$ & & & & \\
GS005 & & $\checkmark$ & & & \\
GS006 & & $\checkmark$ & & & \\
GS007 & & $\checkmark$ & & & \\
GS008 & & $\checkmark$ & & & \\
GS009 & & $\checkmark$ & & & \\
GS010 & & & $\checkmark$ & & \\
GS011 & & & $\checkmark$ & & \\
GS012 & & & $\checkmark$ & & \\
GS013 & & & & $\checkmark$ & \\
GS014 & & & & $\checkmark$ & \\
GS015 & & & & $\checkmark$ &
\end{tabular}




\begin{tabular}{|c|c|c|c|c|c|c|}
\hline GS & DS001 & DS002 & DS003 & DS004 & DS005 & $\overline{\text { DS006 }}$ \\
\hline GS016 & & & & $\checkmark$ & & \\
\hline GS017 & & & & $\checkmark$ & & \\
\hline GS018 & & & & & $\checkmark$ & \\
\hline GS019 & & & & & $\checkmark$ & \\
\hline GS020 & & & & & $\checkmark$ & \\
\hline GS021 & & & & & $\checkmark$ & \\
\hline GS022 & & & & & $\checkmark$ & \\
\hline GS023 & & & & & & $\checkmark$ \\
\hline GS024 & & & & & & $\checkmark$ \\
\hline GS025 & & & & & & $\checkmark$ \\
\hline GS026 & & & & & & $\checkmark$ \\
\hline
\end{tabular}

Dari tabel keputusan tersebut, selanjutnya dibuat pohon keputusan seperti pada Gambar 5 berikut.

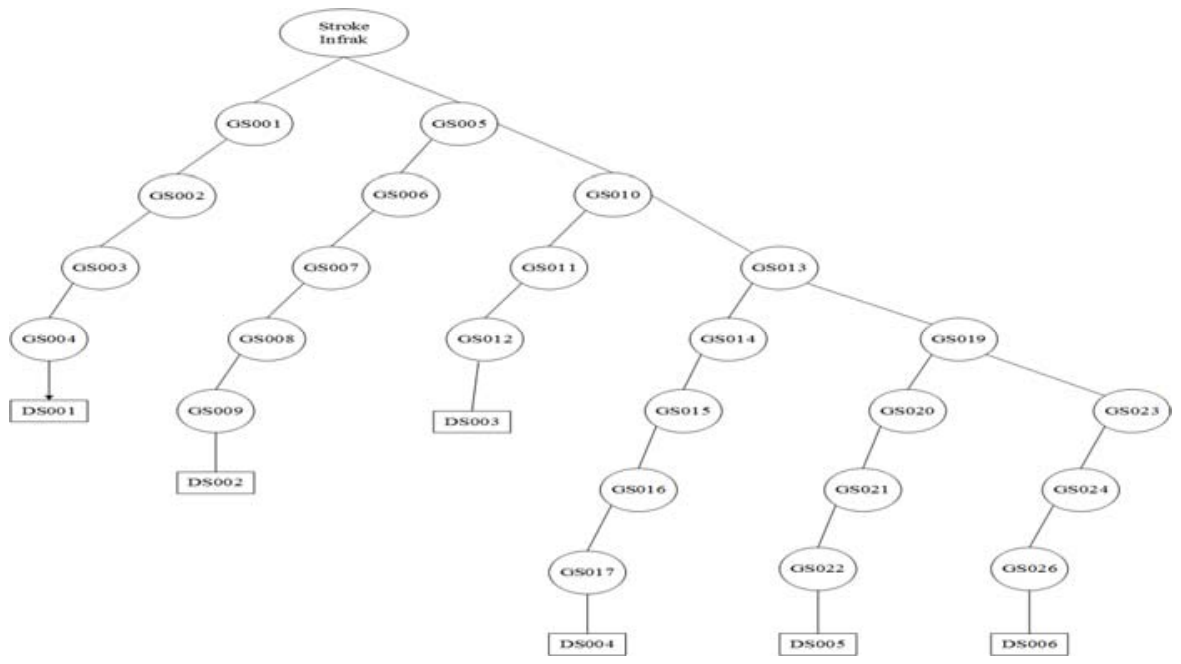

Gambar 4. Pohon Keputusan Diagnosis Keperawatan Penyakit Stroke

Setelah pohon keputusan selanjutnya adalah membentuk Rule untuk kaidah produksi seperti yang disajikan pada Tabel 4 .

Tabel 4. Tabel Kaidah Produksi

\begin{tabular}{lrl}
\hline No & Rule & \multicolumn{1}{c}{ Kaidah Produksi } \\
\hline 1 & Aturan 1 & IF mengalami penurunan kesadaran \\
& & AND merasa gelisah \\
& & AND sakit kepala (pusing) \\
& & AND nyeri dada \\
& & THEN Penurunan Perfusi Jaringan \\
2 & Aturan 2 & IF mengalami kelumpuhan atau kelemahan pada anggota \\
& & tubuh \\
& & AND sulit menggerakan anggota badan \\
& & AND aktivitas dibantu pergerakan lambat
\end{tabular}


AND enggan melakukan pergerakan

AND merasa cemas saat bergerak

THEN Kerusakan Mobilitas Fisik

4 Aturan 4 IF penurunan berat badan

AND makan $1 / 2$ porsi tidak habis

AND nyeri saat menelan

AND kurang minat pada makanan

AND lesu

5 Aturan 5 IF bau badan

AND kuku panjang

AND wajah tampak kusut

AND rambut dan kulit kotor

AND penampilan tidak rapih

THEN Defisit perawatan diri

6 Aturan 6 IF mengeluh adanya luka pada kulit bagian belakang, tumit, betis, punggung

AND Kulit lecet dan kemerahan

AND gatal-gatal pada kulit

AND tidak banyak bergerak

THEN Resiko kerusakan integritas kulit.

\section{Implementasi}

Berikut beberapa tampilan aplikasi sistem pakar diagnosis keperawatan pada penyakit stroke infark.

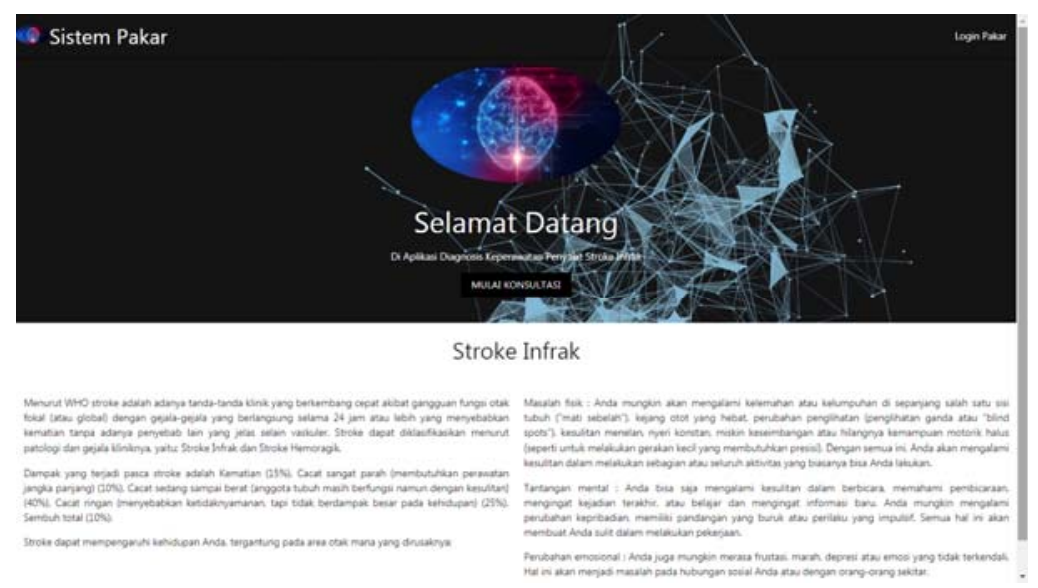

Gambar 5. Sistem Pakar Diagnosis Keperawatan pada Penyaik Stroke Infark

Gambar 6 merupakan tampilan awal pada aplikasi ketika sistem akan digunakan. Pada tampilan tersebut terdapat informasi tentang penyakit stroke infark 
dan menu konsultasi untuk pengguna serta menu login untuk admin (pakar atau administrartor).

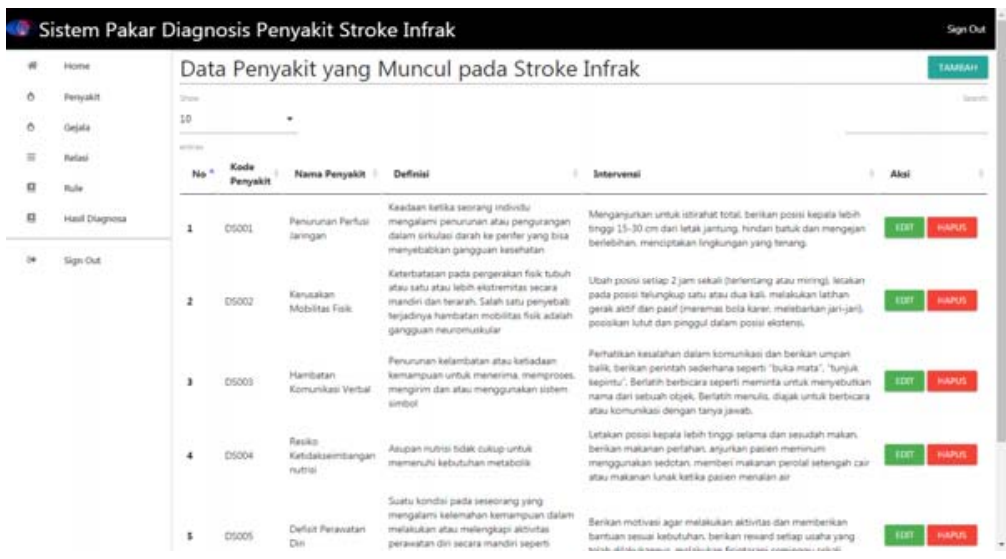

Gambar 7. Halaman Pengelola Data Penyakit

Gambar 7 adalah halaman pengelolaan data penyakit. Pada halaman menu penyakit berisis form data penyakit. Adapun menu pengelolaannya yaitu menu tambah yang digunakan untuk menambahkan data penyakit, menu edit yang digunakan untuk merubah data ada dengan fakta baru, menu hapus untuk meghapus data penyakit dan menu search untuk mencari data.

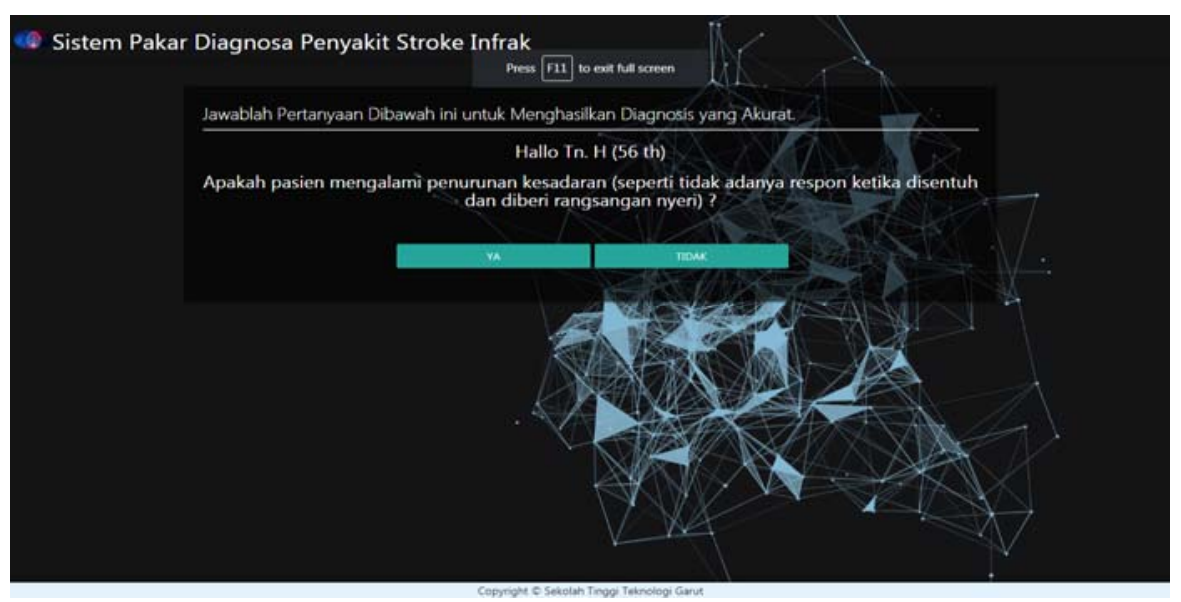

Gambar 8. Halaman Pertanyaan untuk User

Gambar 8 adalah gambar halaman pertnyaan dalam sesi konsultasi pada sistem pakar ini. User harus menjawab pertanyaan yang tersedia dan menjawab sesuai dengan gejala yang dialami saat ini dengan Ya atau Tidak. 


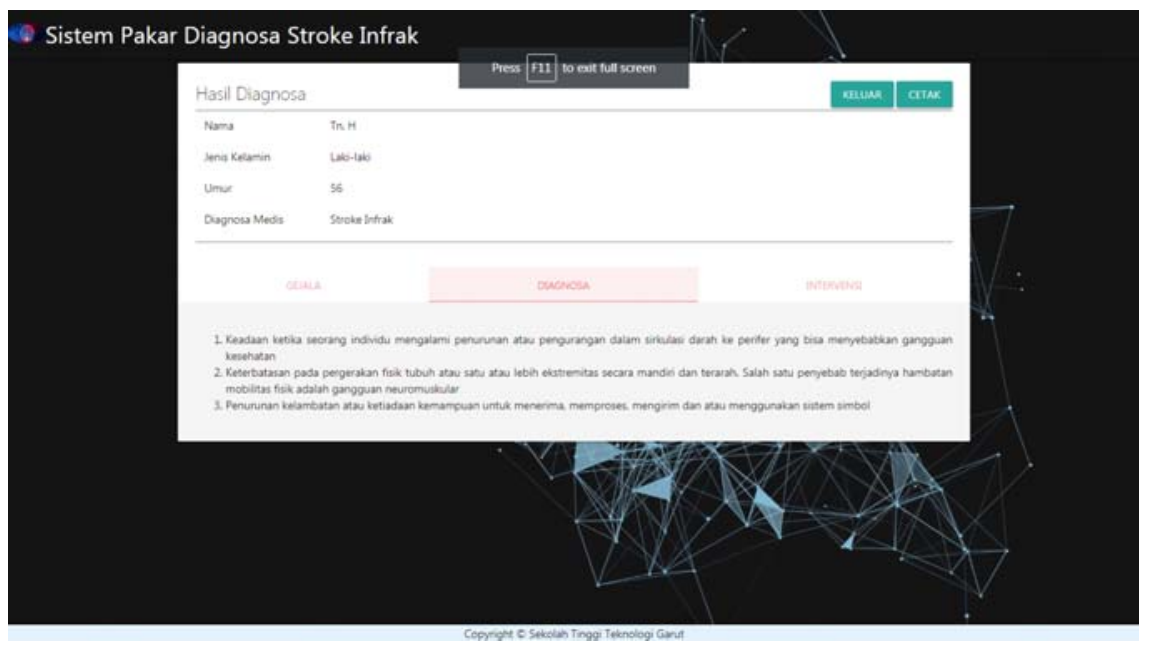

Gambar 9. Halaman Hasil Diagnosa

Gambar 9 adalah tampilan hasil diagnosa yang dilakukan oleh sistem pakar ini. Hasil diagnosa ini dapat diunduh dalam bentuk dokumen berformat pdf.

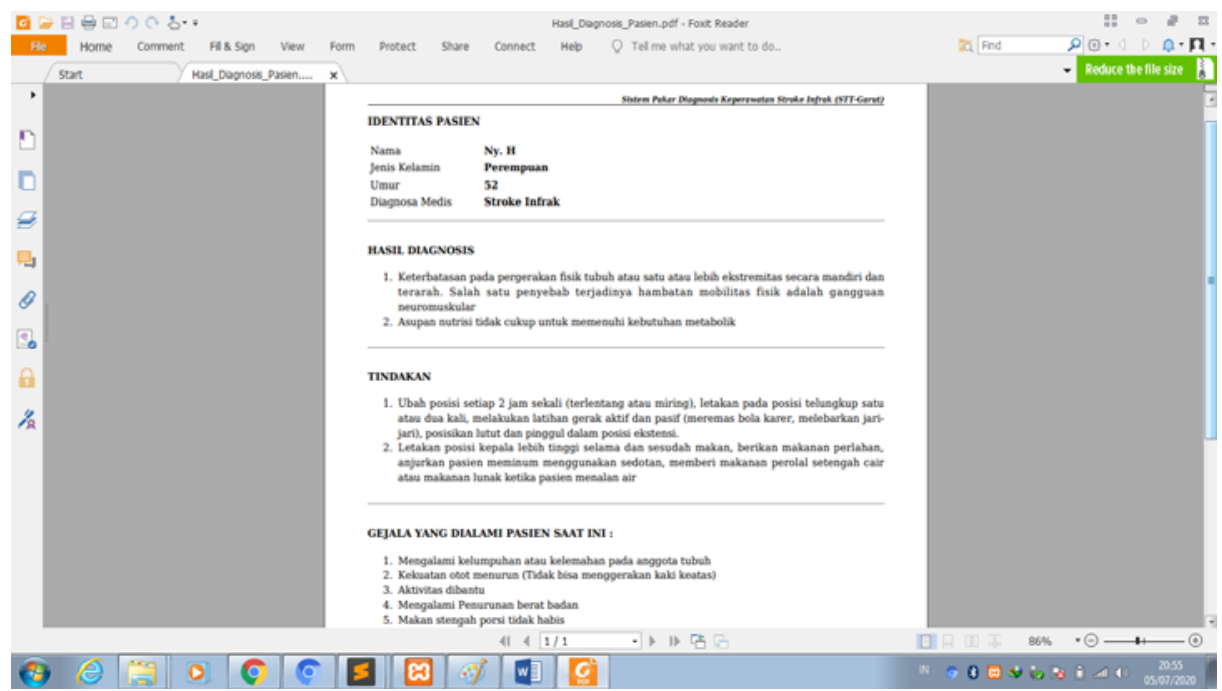

Gambar 60. Hasil Cetak dalam bentuk pdf

Gambar 10 adalah hasil cetak dari sistem pakar. Hasil ini berisi hasil diagnosis berdasarkan gejala yang dialaminya dan intervensi atau tindakan yang dapat diterapkan dirumah supaya mengurangi dampak dari penyakit stroke infark.

4. Pengujian

Aktivitas yang dilakukan pada tahap pengujian ini meliputi pengujian sistem yang dilakukan untuk memenuhi apakah aplikasi dapat layak digunakan oleh 
pengguna. Pengujian sistem yang dilakukan adalah pengujian balck box terhadap semua fitur yang terdapat pada aplikasi sistem pakar diagnosis keperawatan penyakit stroke infrak berbasis website. Hasil dari pengujian blackbox didapatkan bahwa seluruh fungsionalitas sistem pakar diagnosis keperawatan penyakit stroke infrak terpenuhi. Aktivitas perbandingan pengujian diagnosis sistem pakar yang dilakukan dengan membmbandingkan hasil diagnosis yang dihasilkan oleh sistem dengan hasil diagnosis yang dilakukan perawat yang sesungguhnya. Selanjutnya dilakukan pengujian 10 sample berdasarkan hasil diagnosis perawat sesungguhnya. Hasil dari perbandingan pengujian hasil diagnosis sistem menunjukan hasil akurasi yaitu 90 persen.

Pada penelitian sebelumnya yang dilakukan oleh Jansen dan kawan-kawan, nilai akurasi pada sistem pakar yang digunakan untuk mendiagnosis penyakit stroke dengan metode Dempster Shafer menunjukan akurasi sistem yaitu 97 persen [3]. Sedangkan berdasarkan pengujian aplikasi pada penelitian ini dengan mengimplementasikan metode forward chaining menunjukan nilai akurasi 90 persen dan layak untuk digunakan.

\section{Simpulan}

Penelitian ini menghasilkan sistem pakar berbasis website dengan mengimplementasikan metode forward chaining yang berfokus pada diagnosa keperawatan penyakit stroke infrak. Sistem pakar yang dikembangkan dapat mengakuisisi pengetahuan dari para pakar dan memberikan satu atau lebih diagnosa masalah yang muncul pada penyakit stroke infrak dan menyajikan fasilitas bagi pengguna yaitu admin atau pakar dan user (seperti keluarga pasien stroke infrak). Penggunaan metode penarikan kesimpulan forward chaining menunjukan bahwa hasil diagnosis yang diterima oleh pasien telah sesuai dengan yang di diagnosis oleh dokter terkait dengan penyakit stroke infrak. Saran untuk pengembangan berikutnya diantaranya pengetahuan masalah yang muncul pada penyakit stroke infark baru 6 jenis penyakit, dan masih dapat dilakukan pengembangan jenis penyakit yang muncul pada stroke infark yang telah diketahui gejalanya untuk diterapkan pada sistem pakar ini. Sedangkan pada sistem pakarnya dapat dikembangkan dengan menambahkan fitur implementasi intervensi hasil diagnosa sehingga dapat terlihat perubahan kesehatan pada pasien stroke infark.

\section{Daftar Pustaka}

[1] R. Paujiah, "Asuhan Keperawatan pada Tn.A Dengan Gangguan Sistem Persyarafan : Stroke Infrak di Ruang Rubi RSUD dr. Slamet Garut," Garut, 2019.

[2] D. Handayani and D. Dominica, "Gambaran Drug Related Problems 
(DRP's) pada Penatalaksanaan Pasien Stroke Hemoragik dan Stroke Non Hemoragik di RSUD Dr M Yunus Bengkulu," J. Farm. Dan Ilmu Kefarmasian Indones., vol. 5, no. 1, p. 36, 2019, doi: 10.20473/jfiki.v5i12018.36-44.

[3] R. K. S. Putra, "Rancang Bangun Sistem Pakar Diagnosa Penyakit Ayam Dengan Menggunakan Metode Forward Chaining Berbasis Web pada Ternak Ayam Putra Barokah Farm di Kare Madiun," Semin. Nas. Teknol. Inf. dan Komun. 2019, pp. 191-200, 2019.

[4] J. Kanggeraldo, R. P. Sari, and M. I. Zu, "Sistem Pakar Untuk Mendiagnosis Penyakit Stroke Hemoragik dan Iskemik Menggunakan Metode Dempster Shafer," J. RESTI (Rekayasa Sist. dan Teknol. Informasi), vol. 2, no. 2, pp. 498-505, 2018, doi: 10.29207/resti.v2i2.268.

[5] R. Senna Hutama, N. Hidayat, and E. Santoso, "Sistem Pakar Deteksi Dini Penyakit Stroke Menggunakan Metode Naive Bayes-Certainty Factor," J. Pengemb. Teknol. Inf. dan Ilmu Komput., vol. 2, no. 11, pp. 4333-4339, 2018.

[6] I. M. Fadhil, D. D. S. Fatimah, and D. Kurniadi, "Perancangan Aplikasi Sistem Pakar untuk Diagnosis Penyakit pada Ikan Cupang dengan Metode Naive Bayes," J. Algoritm., vol. 16, pp. 255-262, 2019.

[7] H. Nurdiawan and D. D. S. Fatimah, "Pengembangan Sistem Pakar Diagnosis Penyakit Tanaman Tomat Berbasis Visual Prolog," J. Algoritm., vol. 13, no. 1, pp. 114-121, 2016, doi: 10.33364/algoritma/v.13-1.114.

[8] K. R. Saputro and D. Soyusiawaty, "Implementasi Metode Breadth First Search Pada Mesin Inferensi Sistem Pakar Gangguan Kejiwaan Tunawisma," JSTIE (Jurnal Sarj. Tek. Inform., vol. 7, no. 1, pp. 44-51, 2019, doi: 10.12928/jstie.v7i1.15803.

[9] H. Hidayat and D. Kriestanto, "Analisis Metode Sistem Pakar Untuk Menentukan Jenis Penyakit Dalam Dengan Metode Certainty Factor," Univ. Respati Yogyakarta; J. Teknol. Inf., vol. 10, pp. 1-15, 2015, doi: https://doi.org/10.35842/jtir.v10i28.140.

[10] W. Supartini and H. Hindarto, "Sistem Pakar Berbasis Web Dengan Metode Forward Chaining Dalam Mendiagnosa Dini Penyakit Tuberkulosis Di Jawa Timur," Kinetik, vol. 1, no. 3, p. 147, 2016, doi: 10.22219/kinetik.v1i3.123.

[11] A. Pramana gusman, "Sistem Pakar Diagnosa Autis Pada Anak Dengan Menggunakan Metode Forward Chaining," vol. 9, no. 1, pp. 1-8, 2017.

[12] A. Fauzi, "Penerapan Forward Chaining Dalam Sistem Pakar Untuk Mendiagnosis Penyakit Pada Anak," Techno Xplore J. Ilmu Komput. dan Teknol. Inf., vol. 1, no. 1, pp. 11-16, 2016, doi: 10.36805/technoxplore.v1i1.7. 